\title{
JESYA
}

JURNAL EKONOMI \& EKONOMI SYARIAH

Jurnal Ekonomi \& Ekonomi Syariah Vol 3 No 1, Januari 2020

E-ISSN : 2599-3410 | P-ISSN : 2614-3259

DOI : https://doi.org/10.36778/jesya.v3i1.128

\section{Pengaruh Harga dan Kualitas Pelayanan terhadap Keputusan Pembelian pada PT. Sari Melati Kencana Pematangsiantar}

\section{Arwin}

Sekolah Tinggi Akuntansi Dan Manajemen Indonesia arwintannuary18@gmail.com

\section{Debora Silvia Hutagalung}

Sekolah Tinggi Akuntansi Dan Manajemen Indonesia deborahutagalung9@gmail.com

\section{Vanesa Berlien}

Sekolah Tinggi Akuntansi Dan Manajemen Indonesia vanesaberlien123@gmail.com

\begin{abstract}
Abstrak
The rapid development of the business world has resulted in increasingly fierce competition, so that various ways are used by business actors to maintain and develop a competitive advantage with its competitors. In the era of modernization like today, a practical and instantaneous lifestyle has developed which affects almost the entire human population in the world. Instant lifestyle is a lifestyle that prioritizes practicality, speed and time efficiency. For some people, fast, practical and efficient have become the main needs in their daily activities. This certainly has an effect on business competition, which is then responded by most manufacturers in designing products that suit the needs of people's instant lifestyles. A business that is influenced by people's lifestyle is the restaurant business of PT. Sari Melati Kencana Pematangsiantar. Data collection methods used in this research are questionnaires, interviews, documentation and observation. The population in this study was 40 people and the number of samples in this study was 40 people because the sampling technique in this study was the census method. The data analysis technique used was the instrument test, namely validity and reliability tests, classic assumption tests, namely normality tests and hypothesis tests, namely multiple linear regression, correlation coefficient, determination coefficient, partial test ( $t$ test), and simultaneous test ( $F$ test). The results showed that: $(1)$ price has a positive effect on purchasing decisions, this is evidenced by the value of tcount> ttable (4.452> 2.026) with a significance value of 0.000 (sig $\leq 0.05)$, (2) service quality has a positive effect on the decision. purchases with tcount $>$ ttable $(7,401>2,026)$ with a significance value of 0,000 (sig $\leq 0.05$ ), (3) price and service quality have a positive effect on purchasing decisions, this is evidenced by the value of Fcount> Ftable $(49.320>3,25)$ with a significance value of 0.000 (sig $\leq 0.05)$
\end{abstract}

Keywords $\quad$ Price, Service Quality and Purchasing Decisions

\section{PENDAHULUAN}

Perkembangan dunia bisnis yang semakin pesat mengakibatkan persaingan semakin ketat sehingga berbagai cara dilakukan para pelaku bisnis untuk menjaga dan mengembangkan keunggulan kompetitif dengan pesaingnya. Perubahan kebudayaan biasanya ditunjukkan oleh perubahan gaya hidup. Pada era modernisasi seperti saat ini, berkembang gaya hidup serba praktis dan instan yang mempengaruhi hampir 
seluruh populasi manusia yang ada di dunia. Gaya hidup instan adalah gaya hidup yang mengutamakan nilai kepraktisan, kecepatan dan efisiensi waktu. Bagi beberapa orang, cepat, praktis dan efesien sudah menjadi sebuha kebutuhan utama di dalam kegiatannya sehari-hari. Hal ini tentu berpengaruh terhadap persaingan bisnis, yang kemudian direspon oleh kebanyakan produsen dalam merancang produk yang sesuai dengan kebutuhan gaya hidup instan masyarakat. Bisnis yang terpengaruh oleh gaya hidup masyarakat adalah bisnis restoran. Dalam prosesnya, keputusan pembelian merupakan tindakan yang dilakukan pelanggan untuk membeli suatu produk. Pada dasarnya, pengambilan keputusan pembelian setiap orang sama namun proses dalam pengambilan keputusan pembelian pasti berbeda-beda. Adapun proses keputusan pembelian pelanggan melalui lima tahapan yaitu pengenalan masalah, pencarian informasi, evaluasi alternatif, keputusan pembelian, dan evaluasi pasca pembelian. Pada PT. Sari Melati Kencana Pematangsiantar sebelum memutuskan untuk membeli, biasanya pelanggan akan mengenali masalah yang dihadapi yaitu tujuan untuk membeli produk tersebut. Selanjutnya pelanggan akan mencari informasi mengenai kebutuhan yang diinginkan serta mencari keberadaan PT. Sari Melati Kencana Pematangsiantar.

Selain itu pada dimensi evaluasi alternatif yaitu pilihan menu yang ditawarkan oleh PT. Sari Melati Kencana Pematangsiantaryang berbeda-beda jenisnya sehingga pelanggan mempunyai banyak pilihan akan kebutuhan dan keinginannya. Lalu pada dimensi keputusan pembelian yaitu pelanggan menetapkan pilihannya membeli kuliner tersebut sesuai dengan keiinginannya. Pada dimensi perilaku setelah pembelian yaitu pelanggan yang kembali melakukan pembelian bahan bangunan yang ditawarkan oleh PT. Sari Melati Kencana Pematangsiantar bahkan turut serta dalam melakukan penjualan bahan bangunan tersebut kepada masyarakat.

Salah satu faktor yang mempengaruhi keputusan pembelian adalah harga. Harga yang diberikan PT. Sari Melati Kencana Pematangsiantardapat diukur dalam tiga dimensi yaitu keterjangkauan harga, potongan harga dan cara pembayaran. Pada aspek keterjangkauan harga, dimana PT. Sari Melati Kencana Pematangsiantar memberikan penawaran harga yang cukup tinggi kepada pelanggan, sehingga tidak jarang pelanggan melakukan perbandingan harga dengan penawaran yang diberikan PT. Sari Melati Kencana Pematangsiantar dan memutuskan untuk membeli di tempat lain. Potongan harga yang diberikan oleh PT. Sari Melati Kencana Pematangsiantar masih belum memuaskan pelanggan dikarenakan pelanggan harus membeli produk dalam jumlah banyak agar bisa memperoleh potongan harga. Sedangkan cara pembayaran yang ada pada PT. Sari Melati Kencana Pematangsiantar hanya memiliki dua cara pembayaran yaitu tunai dan kredit saja, serta belum tersedianya layanan pembayaran melalui debet card atau internet banking.

Faktor lain yang mempengaruhi keputusan pembelian adalah kualitas pelayanan. Kualitas pelayanan pada PT. Sari Melati Kencana Pematangsiantar dapat diukur dalam lima dimensi yaitu kehandalan, jaminan, bukti fisik, empati, dan daya tanggap. Implementasi kualitas pelayanan yang dilakukan oleh PT. Sari Melati Kencana Pematangsiantar dapat dilihat pada dimensi kehandalan dimana karyawan PT. Sari Melati Kencana Pematangsiantar memberikan pelayanan sesuai dengan prosedur yang dijanjikan dengan menghindari kesalahan-kesalahan yang fatal. Kemudian pada dimensi jaminan dimana PT. Sari Melati Kencana Pematangsiantar memberikan jaminan dalam hal keamanan bertransaksi maupun privasi pelanggan. Selain itu pada dimensi bukti fisik dimana PT. Sari Melati Kencana Pematangsiantar menyediakan fasilitas ruangan yang nyaman bagi pelanggannya. Lalu dimensi empati dimana karyawan PT. Sari Melati Kencana Pematangsiantar memiliki kemampuan komunikasi dan memahami kebutuhan khusus pelanggan, dan pada dimensi daya tanggap dimana karyawan PT. Sari Melati Kencana Pematangsiantar memiliki kemampuan dalam menanggapi permintaan, keluhan maupun saran yang diberikan pelanggan.

Demi kepuasan pelanggannya, PT. Sari Melati Kencana Pematangsiantar meningkatkan pelayanannya dengan mengantarkan produk langsung kepada pembelinya. Kegiatan tersebut dinamakan delivery. Oleh karena itu, PT. Sarimelati Kencana mendirikan PT. Sari Melati Kencana Pematangsiantar 
Delivery (PHD). Produk yang ditawarkan PHD antara lain: produk, pasta, makanan pembuka, dan minuman yang dapat dibeli secara langsung ke outlet (take away) dan dikirim ke rumah pelanggan (delivery).

\section{LANDASAN TEORI Keputusan Pembelian}

Keputusan pembelian akan menentukan proses dalam menentukan pembelian yang dilakukan konsumen dalam memutuskan apa, kapan, dimana, dan bagaimana melakukan pembelian. Keputusan pembelian merupakan suatu proses pengambilan keputusan akan pembelian yang mencakup penentuan apa yang akan dibeli atau tidak melakukan pembelian (Assauri, 2004 : 141). Menurut Kotler (2002 : 204) keputusan pembelian merupakan suatu tindakan dari konsumen untuk membentuk referensi diantara kelompok pilihan dan mau menggunakan atau tidak terhadap produk atau jasa yang ditawarkan. Dari pengertian keputusan pembelian di atas dapat disimpulkan bahwa keputusan pembelian adalah perilaku pembelian seseorang dalam menentukan suatu pilihan produk untuk mencapai kepuasan sesuai kebutuhan dan keinginan konsumen yang meliputi pengenalan masalah, pencarian informasi, evaluasi terhadap alternatif pembelian, keputusan pembelian, dan perilaku setelah pembelian.

\section{Harga}

Semua jasa yang ditawarkan oleh perusahaan pasti mempunyai harga. Agar jasa tersebut laku dipasaran, perusahaan harus menetapkan harga yang tepat. Dengan adanya harga, konsumen dapat membandingkan jasa yang satu dengan yang lainnya, sehingga membantu konsumen menentukan keputusan pembelian. Harga dikatakan mahal, murah atau biasa-biasa saja dari setiap individu tidaklah harus sama, karena tergantung dari persepsi individu yang dilatar belakangi oleh lingkungan kehidupan dan kondisi individu. Menurut Tjiptono (2001:151), harga merupakan satuan moneter atau ukuran lainnya (termasuk barang dan jasa) yang ditukarkan agar memperoleh hak kepemilikan atau penggunaan suatu jasa. Menurut Kotler dan Amstrong (2008 : 62), harga merupakan jumlah uang yang harus dibayar konsumen untuk memperoleh produk atau jasa. Menurut Basu Swastha dan Irawan (2000 : 241), harga adalah sejumlah pengorbanan yang dilakukan untuk mendapatkan kombinasi barang dan jasa. Dari uraian diatas, dapat disimpulkan bahwa harga merupakan sejumlah nilai yang ditukarkan konsumen untuk dapat mengunakan suatu jasa. Penting bagi perusahaan menetapkan harga yang sesuai atau wajar dengan nilai (value) dari jasanya.

\section{Kualitas Pelayanan}

Kualitas pelayanan mempunyai hubungan langsung dengan keputusan pembelian dan kemampuan bersaing dengan tingkatan keuntungan yang diperoleh perusahaan. Karena itu kualitas pelayanan perlu mendapat perhatian yang besar dari manajer. Menurut Kotler dan Amstrong (2008 : 347) menyatakan bahwa kualitas pelayanan merupakan kemampuan suatu jasa untuk melakukan fungsi-fungsinya yang meliputi keandalan, daya tahan, ketepatan, kemudahan, operasi dan perbaikan serta atribut lainnya. Bila suatu jasa telah dapat menjalankan fungsi-fungsinya dapat dikatakan sebagai jasa yang berkualitas baik.

Menurut Parasuraman, dkk (Lupioadi, 2006 : 181) kualitas pelayanan didefinisikan sebagai seberapa jauh perbedaan antara kenyataan dengan harapan pengunjung atas layanan yang mereka terima. Kualitas pelayanan juga didefinisikan sebagai evaluasi menyeluruh pelanggan atas kebaikan kinerja suatu jasa (Mowen dan Minor, 2002 : 90).

\section{METODE PENELITIAN Rancangan Penelitian}

Rancangan penelitian merupakan gambaran atau deskripsi yang terinci dan mendetail tentang komponen penelitian, sehingga rancangan penelitian digunakan sebagai petunjuk dalam melaksanakan penelitian. Adapun desain penelitian yang penulis gunakan dalam penulisan laporan ini adalah: 
1. Penelitian Kepustakaan (Library Research)

Teknik pengumpulan data yang dilakukan dengan menggunakan data sekunder yang berwujud teori dan lain-lain. Dalam metode ini, penelitian dilakukan langsung dengan cara mencari informasi melalui internet, catatan kuliah dan referensi lainnya yang berhubungan dengan kualitas pelayanan, harga, dan keputusan pembelian pelanggan.

2. Penelitian Lapangan (Field Research)

Penelitian yang dilakukan dengan cara melakukan peninjauan langsung ke lokasi penelitian. Penelitian ini dilakukan dengan cara mendapatkan data langsung dari wawancara terhadap pimpinan, karyawan dan pelanggan PT. SARI MELATI KENCANA PEMATANGSIANTAR.

\section{Ruang Lingkup Penelitian}

Ruang lingkup penelitian ini membahas mengenai harga, kualitas pelayanan dan keputusan pembelian. Dimensi harga terdiri dari keterjangkauan harga, potongan harga, dan cara pembayaran. Dimensi kualitas pelayanan terdiri dari kehandalan, jaminan, bukti fisik, empati dan daya tanggap. Dimensi keputusan pembelian terdiri dari pengenalan masalah, pencarian informasi, evaluasi alternatif, keputusan pembelian dan evaluasi pasca pembelian.

\section{Populasi dan Sampel}

Menurut Sugiyono (2017:80), populasi adalah wilayah generalisasi yang terdiri atas objek/subjek yang mempunyai kualitas dan karakteristik tertentu yang ditetapkan oleh peneliti untuk dipelajari dan kemudian ditarik kesimpulannya. Dalam hal ini penulis mengambil populasi dari jumlah pada bulan Juni tahun 2019 pada PT. Sari Melati Kencana Pematangsiantar yang digunakan sebagai bahan penelitian. Adapun jumlah pelanggan yang datang pada bulan Juni ke PT. Sari Melati Kencana Pematangsiantar adalah sebanyak 40 orang. Sampel dapat dideinisikan sebagai sekumpulan data yang diambil atau dipilih dari suatu populasi (Santoso, 2001). Pengertian lain, sampel adalah subset dari populasi, terdiri dari beberapa anggota populasi. Subset ini diambil karena dalam banyak kasus tidak mungkin kita mewakili seluruh anggota populasi, oleh karena itu kita membentuk sebuah perwakilan populasi yang disebut sampel (Ferdinand, 2006).

Dengan menggunakan metode purposive sampling, yaitu pengambilan sampel dilakukan dengan pertimbangan-pertimbangan tertentu, dengan memperhatikan responden yang dikehendaki untuk memudahkan penelitian sehingga diambil sampel sebanyak 40 orang yang pernah mengkonsumsi produk PT. Sari Melati Kencana Pematangsiantar(Sugiono, 2004).

\section{Teknik Analisis Data \\ Uji Validitas}

Pengertian uji validitas yaitu suatu ukuran yang menunjukkan tingkat ketepatan dan kesalahan suatu instrumen. Instrumen harus dapat mengukur apa yang seharusnya diukur, jadi validitas menekankan pada alat pengukur pengamatan. Kegunaan validitas yaitu untuk mengetahui sejauh mana ketepatan dan kecermatan suatu instrumen pengukuran dalam melakukan fungsi ukurannya. Menurut Sugiyono (2017:134), bila koefisien korelasi sama dengan 0,30 atau lebih (paling kecil 0,3), maka butir instrumen dinyatakan valid. Untuk melakukan uji validitas digunakan bantuan SPSS versi 22.

\section{Uji Reliabilitas}

Uji reliabilitas merupakan alat untuk mengukur suatu kuesioner yang merupakan indikator dari variabel. Uji reliabilitas digunakan untuk mengetahui apakah alat pengumpulan data menunjukkan tingkat ketepatan, tingkat keakuratan, kestabilan atau konsistensi dalam mengungkapkan gejala tertentu. Suatu 
kuesioner dikatakan reliabel atau handal jika jawaban seseorang terhadap pernyataan adalah konsisten atau stabil dari waktu ke waktu.

\section{Uji Normalitas}

Uji normalitas dimaksud untuk menentukan rumus yang akan digunakan dalam uji hipotesis dan untuk mengetahui apakah data tersebut berdistribusi normal atau tidak. Jika data tersebut berdistribusi normal maka proses selanjutnya dalam pengujian hipotesis dapat menggunakan perhitungan statistik parametris. Tetapi jika datanya tidak berdistribusi normal maka pengujian hipotesisnya menggunakan perhitungan statistik non parametris.

\section{Uji Hipotesis}

Uji hipotesis adalah cabang ilmu statistika inferensial yang dipergunakan untuk menguji kebenaran suatu pernyataan secara statistik dan menarik kesimpulan apakah menerima atau menolak pernyataan tersebut. Penulis menganalisis data melalui penelitian yang dilakukan pada PT. SARI MELATI KENCANA PEMATANGSIANTAR Pematangsiantar, maka dari penelitian tersebut didapatkan hasil pengolahan data adalah dengan uji Regresi linier berganda digunakan peneliti dengan maksud untuk mengetahui ada atau tidaknya pengaruh harga dan kualitas pelayanan terhadap keputusan pembelian. Persamaan yang dinyatakan dalam bentuk hubungan antara variabel independent (X) dan variabel dependent $(\mathrm{Y})$ disebut dengan persamaan regresi.

\section{HASIL DAN PEMBAHASAN \\ Deskripsi Responden}

Dalam sebuah penelitian deskripsi data itu penting untuk memberikan gambaran data yang kita teliti. Selain itu, dengan adanya dekripsi data, pembaca akan lebih mudah untuk mengetahui paparan data dalam sebuah penelitian secara lebih terperinci dan jelas. Adapun hasil deskripsi responden dalam penelitian ini adalah sebagai berikut

Tabel Deskripsi Responden

\begin{tabular}{|l|r|r|r|r|r|}
\hline & \multicolumn{1}{|c|}{ D } & Minimum & Maximum & \multicolumn{1}{c|}{ Mean } & Std. Deviation \\
\hline Harga & 40 & 10 & 15 & 12.37 & 1.234 \\
Kualitas Pelayanan & 40 & 15 & 25 & 18.08 & 2.368 \\
Keputusan Pembelian & 40 & 12 & 25 & 16.43 & 2.836 \\
Unstandardized Residual & 40 & -4.02439 & 2.85360 & .0000000 & 1.48143881 \\
Valid N (listwise) & 40 & & & & \\
\hline
\end{tabular}

Sumber: Hasil pengolahan data deskripsi responden menggunakan SPSS versi 2

Berdasarkan hasil deskripsi responden pada tabel 5.1 di atas menunjukkan jumlah responden (N) ada 40 orang. Dari 40 responden ini, nilai $\mathrm{X}_{1}$ (harga) terendah (minimum) adalah 10 dan nilai $\mathrm{X}_{1}$ (harga) tertinggi (maximum) adalah 15. Rata-rata (mean) nilai dari 40 responden untuk $\mathrm{X}_{1}$ (harga) adalah 12,37 dengan standar deviasi sebesar 1,234. Sedangkan nilai $\mathrm{X}_{2}$ (kualitas pelayanan) terendah (minimum) adalah 15 dan nilai $\mathrm{X}_{2}$ (kualitas pelayanan) tertinggi (maximum) adalah 25. Rata-rata (mean) nilai dari 40 responden untuk $\mathrm{X}_{2}$ (kualitas pelayanan) adalah 18,08 dengan standar deviasi sebesar 2,368. Dan nilai $\mathrm{Y}$ (keputusan pembelian) terendah (minimum) adalah 12 dan nilai Y (keputusan pembelian) tertinggi (maximum) adalah 25. Rata-rata (mean) nilai dari 40 responden untuk Y (keputusan pembelian) adalah 16,43 dengan standar deviasi sebesar 2,836. 


\section{Uji Validitas}

Uji validitas adalah metode pengujian yang digunakan untuk mengetahui pernyataan-pernyataan kuesioner yang harus dibuang atau diganti karena dianggap tidak relevan. Pengujiannya dilakukan secara statistik, yang dilakukan dengan bantuan program IBM Statistical for Product and Service Solution (SPSS) versi 22. Teknik untuk mengukur validitas kuesioner adalah dengan menghitung korelasi antar data pada masing-masing pernyataan dengan skor total. Item instrumen dianggap valid jika lebih besar dari 0,3 atau bisa juga membandingkannya dengan $r_{\text {kritis. }}$ Jika $r_{\text {hitung }}>r_{\text {kritis }}$ maka valid. Adapun hasil uji validitas dalam penelitian ini dapat dilihat pada tabel berikut:

Tabel Hasil Uji Validitas

\begin{tabular}{|c|c|c|c|c|c|}
\hline Variabel & Dimensi & $\begin{array}{c}\text { Butir } \\
\text { Instrumen }\end{array}$ & $\mathrm{r}_{\text {hitung }}$ & $\mathrm{r}_{\text {kritis }}$ & Keterangan \\
\hline \multirow{3}{*}{ Harga $\left(X_{1}\right)$} & $\begin{array}{c}\text { Keterjangkauan } \\
\text { Harga }\end{array}$ & $\mathrm{X} 1.1$ & 0,601 & 0,3 & Valid \\
\hline & Potongan Harga & $\mathrm{X} 1.2$ & 0,646 & 0,3 & Valid \\
\hline & Cara Pembayaran & $\mathrm{X} 1.3$ & 0,758 & 0,3 & Valid \\
\hline \multirow{5}{*}{$\begin{array}{l}\text { Kualitas } \\
\text { Pelayanan } \\
\quad\left(\mathrm{X}_{2}\right)\end{array}$} & $\begin{array}{l}\text { Kehandalan } \\
\text { (Reliability) }\end{array}$ & $\mathrm{X} 2.1$ & 0,604 & 0,3 & Valid \\
\hline & Jaminan (Assurance) & $\mathrm{X} 2.2$ & 0,774 & 0,3 & Valid \\
\hline & $\begin{array}{c}\text { Bukti Fisik } \\
(\text { Tangible })\end{array}$ & $\mathrm{X} 2.3$ & 0,693 & 0,3 & Valid \\
\hline & Empati (Empathy) & $\mathrm{X} 2.4$ & 0,712 & 0,3 & Valid \\
\hline & $\begin{array}{l}\text { Daya Tanggap } \\
\text { (Responsiveness) }\end{array}$ & $\mathrm{X} 2.5$ & 0,774 & 0,3 & Valid \\
\hline \multirow{5}{*}{$\begin{array}{c}\text { Keputusan } \\
\text { Pembelian } \\
\text { (Y) }\end{array}$} & Pengenalan Masalah & Y.1 & 0,825 & 0,3 & Valid \\
\hline & Pencarian Informasi & Y.2 & 0,712 & 0,3 & Valid \\
\hline & Evaluasi Alternatif & Y.3 & 0,860 & 0,3 & Valid \\
\hline & $\begin{array}{l}\text { Keputusan } \\
\text { Pembelian } \\
\end{array}$ & Y.4 & 0,409 & 0,3 & Valid \\
\hline & $\begin{array}{c}\text { Evaluasi Pasca } \\
\text { Pembelian }\end{array}$ & Y.5 & 0,626 & 0,3 & Valid \\
\hline
\end{tabular}

Sumber: Hasil pengolahan data uji validitas menggunakan SPSS versi 22

Berdasarkan hasil uji validitas pada tabel 5.2 di atas, diketahui bahwa nilai $\mathrm{r}_{\text {hitung }}$ dari semua instrumen lebih besar daripada $r_{\text {kritis }}$ maka dapat disimpulkan bahwa semua instrumen dari variabel dalam penelitian ini adalah valid.

\section{Uji Reliabilitas}

Uji reliabilitas adalah metode pengujian yang digunakan untuk menetapkan apakah instrumen yang dalam hal ini kuesioner dapat digunakan lebih dari satu kali, paling tidak oleh responden yang sama akan menghasilkan data yang konsisten. Pengujiannya dilakukan secara statistik, yang dilakukan dengan bantuan program IBM Statistical for Product and Service Solution (SPSS) versi 22. Reliabilitasnya dengan uji statistik Cronbach's Alpha.

Dengan kata lain reliabilitas instrumen mencirikan tingkat konsistensi. Nilai koefisien reliabilitas dikatakan reliabel jika nilai Cronbach's Alpha if Item Deleted $=0,70$. Adapun hasil uji reliabilitas dalam penelitian ini dapat dilihat dalam tabel berikut: 
Jurnal Ekonomi \& Ekonomi Syariah Vol 3 No 1, Januari 2020

E-ISSN : 2599-3410 | P-ISSN : 2614-3259

DOI : https://doi.org/10.36778/jesya.v3i1.128

Tabel Hasil Uji Reliabilitas

\begin{tabular}{|c|c|c|c|}
\hline Variabel & Dimensi & $\begin{array}{c}\text { Cronbach's } \\
\text { Alpha }\end{array}$ & Keterangan \\
\hline \multirow{9}{*}{ Harga $\left(X_{1}\right)$} & \multirow{3}{*}{$\begin{array}{l}\text { Keterjangkauan } \\
\text { Harga }\end{array}$} & 0,70 & Reliabel \\
\hline & & 0,70 & Reliabel \\
\hline & & 0,70 & Reliabel \\
\hline & \multirow{3}{*}{ Potongan Harga } & 0,70 & Reliabel \\
\hline & & 0,70 & Reliabel \\
\hline & & 0,70 & Reliabel \\
\hline & \multirow{3}{*}{ Cara Pembayaran } & 0,70 & Reliabel \\
\hline & & 0,70 & Reliabel \\
\hline & & 0,70 & Reliabel \\
\hline \multirow{15}{*}{$\begin{array}{l}\text { Kualitas } \\
\text { Pelayanan } \\
\quad\left(\mathrm{X}_{2}\right)\end{array}$} & \multirow{3}{*}{$\begin{array}{l}\text { Kehandalan } \\
\text { (Reliability) }\end{array}$} & 0,70 & Reliabel \\
\hline & & 0,70 & Reliabel \\
\hline & & 0,70 & Reliabel \\
\hline & \multirow{3}{*}{$\begin{array}{c}\text { Jaminan } \\
\text { (Assurance) }\end{array}$} & 0,70 & Reliabel \\
\hline & & 0,70 & Reliabel \\
\hline & & 0,70 & Reliabel \\
\hline & \multirow{3}{*}{$\begin{array}{l}\text { Bukti Fisik } \\
\text { (Tangible) }\end{array}$} & 0,70 & Reliabel \\
\hline & & 0,70 & Reliabel \\
\hline & & 0,70 & Reliabel \\
\hline & \multirow{3}{*}{ Empati (Empathy) } & 0,70 & Reliabel \\
\hline & & 0,70 & Reliabel \\
\hline & & 0,70 & Reliabel \\
\hline & \multirow{3}{*}{$\begin{array}{c}\text { Daya Tanggap } \\
\text { (Responsiveness) }\end{array}$} & 0,70 & Reliabel \\
\hline & & 0,70 & Reliabel \\
\hline & & 0,70 & Reliabel \\
\hline \multirow{15}{*}{$\begin{array}{c}\text { Keputusan } \\
\text { Pembelian } \\
\text { (Y) }\end{array}$} & \multirow{3}{*}{$\begin{array}{l}\text { Pengenalan } \\
\text { Masalah }\end{array}$} & 0,70 & Reliabel \\
\hline & & 0,70 & Reliabel \\
\hline & & 0,70 & Reliabel \\
\hline & \multirow{3}{*}{ Pencarian Informasi } & 0,70 & Reliabel \\
\hline & & 0,70 & Reliabel \\
\hline & & 0,70 & Reliabel \\
\hline & \multirow{3}{*}{ Evaluasi Alternatif } & 0,70 & Reliabel \\
\hline & & 0,70 & Reliabel \\
\hline & & 0,70 & Reliabel \\
\hline & \multirow{3}{*}{$\begin{array}{l}\text { Keputusan } \\
\text { Pembelian }\end{array}$} & 0,70 & Reliabel \\
\hline & & 0,70 & Reliabel \\
\hline & & 0,70 & Reliabel \\
\hline & \multirow{3}{*}{$\begin{array}{l}\text { Evaluasi Pasca } \\
\text { Pembelian }\end{array}$} & 0,70 & Reliabel \\
\hline & & 0,70 & Reliabel \\
\hline & & 0,70 & Reliabel \\
\hline
\end{tabular}

Sumber: Hasil pengolahan data uji reliabilitas menggunakan SPSS versi 22

Berdasarkan hasil uji reliabilitas pada tabel 5.3 di atas, diketahui bahwa semua instrumen Cronbach's Alpha if Item Deleted sama dengan 0,70. Hal ini berarti instrumen dalam penelitian ini adalah reliabel. 


\section{Uji Normalitas}

Uji normalitas dilakukan untuk memeriksa apakah populasi berdistribusi normal atau tidak, maka teknik yang digunakan untuk menghitung menggunakan bantuan SPSS versi 22. Berikut ini merupakan tabel One-Sample Kolmogorov-Smirnov:

Tabel Hasil Uji Normalitas

One-Sample Kolmogorov-Smirnov Test

\begin{tabular}{|ll|r|}
\hline & & $\begin{array}{r}\text { Unstandardiz } \\
\text { ed Residual }\end{array}$ \\
\hline Normal Parameters & a,b & Mean \\
& Std. Deviation & .0000000 \\
Most Extreme Differences & Absolute & .48143881 \\
& Positive & .070 \\
Test Statistic & Negative & -.070 \\
Asymp. Sig. (2-tailed) & & .070 \\
\hline
\end{tabular}

a. Test distribution is Normal.

b. Calculated from data

c. Lilliefors Significance Correction.

d. This is a lower bound of the true siqnificance.

Sumber: Hasil pengolahan data uji normalitas menggunakan SPSS versi 22

Berdasarkan tabel hasil uji normalitas One-Sample Kolmogorov-Smirnov Test di atas dapat dilihat nilai Asymp. Sig (2-tailed) pada Unstandardized Residual sebesar 0,200 lebih besar dari a 0,05. Dengan demikian, dapat dinyatakan bahwa distribusi data dari masing-masing data variabel berdistribusi normal.

\section{Regresi Linier Berganda}

Regresi linier berganda dilakukan untuk menganalisa pengaruh variabel $\mathrm{X}_{1}$ (harga) dan variabel $\mathrm{X}_{2}$ (kualitas pelayanan) terhadap variabel Y (keputusan pembelian) pada PT. Sari Melati Kencana Pematangsiantar Pematangsiantar. Dengan menggunakan bantuan SPSS versi 22, maka diperoleh hasil regresi linier berganda seperti terangkum pada tabel berikut ini:

Tabel Hasil Analisis Regresi Linier Berganda Coefficients $^{a}$

\begin{tabular}{|c|c|c|c|c|c|c|}
\hline \multirow[b]{2}{*}{ Mode } & & \multicolumn{2}{|c|}{ Unstandardized Coefficients } & \multirow{2}{*}{$\begin{array}{c}\text { Standardized } \\
\text { Coefficients }\end{array}$} & \multirow[b]{2}{*}{$t$} & \multirow[b]{2}{*}{ Sig. } \\
\hline & & $\mathrm{B}$ & Std. Error & & & \\
\hline \multirow[t]{3}{*}{1} & (Constant) & -9.097 & 2.760 & & -3.296 & .002 \\
\hline & Harga & .911 & .205 & .396 & 4.452 & .000 \\
\hline & Kualitas Pelayanan & .789 & .107 & .658 & 7.401 & .000 \\
\hline
\end{tabular}

Sumber: Hasil pengolahan data regresi linier berganda menggunakan SPSS versi 22

Berdasarkan hasil pengolahan data pada tabel di atas, diperoleh nilai $\mathrm{R}=0,853$, yang artinya terdapat hubungan yang sangat kuat dan positif antara harga dan kualitas pelayanan terhadap keputusan pembelian pada PT. Sari Melati Kencana Pematangsiantar Pematangsiantar. Kemudian diperoleh nilai koefisien determinasi $(R$ Square $)=0,727$ artinya tinggi rendahnya keputusan pembelian (Y) sebesar 72,7\% dapat dipengaruhi oleh faktor harga $\left(X_{1}\right)$ dan kualitas pelayanan $\left(X_{2}\right)$, sedangkan sisanya 27,3\% dipengaruhi oleh faktor lain seperti promosi, lokasi dan lain sebagainya yang tidak dibahas dalam penelitian ini.

\section{Uji Parsial (Uji t)}


Pengujian ini dilakukan secara parsial yaitu dilakukan untuk menentukan diterima atau ditolaknya hipotesis, pengujian hipotesis dilakukan untuk menguji apakah variabel harga dan kualitas pelayanan yang diuji berpengaruh terhadap keputusan pembelian. Jika $t_{\text {hitung }}>t_{\text {tabel }}$ atau signifikasi $\leq 0,05$, maka $\mathrm{H}_{0}$ ditolak.

Dengan menggunakan bantuan SPSS versi 22, maka diperoleh hasil perhitungan thitung seperti pada tabel berikut ini:

Tabel Hasil Uji Parsial (Uji t)

Coefficients $^{\mathrm{a}}$

\begin{tabular}{|c|c|c|c|c|c|c|}
\hline \multirow{2}{*}{\multicolumn{2}{|c|}{ Model }} & \multicolumn{2}{|c|}{ Unstandardized Coefficients } & \multirow{2}{*}{$\begin{array}{c}\begin{array}{c}\text { Standardized } \\
\text { Coefficients }\end{array} \\
\text { Beta }\end{array}$} & \multirow[b]{2}{*}{$t$} & \multirow[b]{2}{*}{ Sig. } \\
\hline & & $\mathrm{B}$ & Std. Error & & & \\
\hline \multirow[t]{3}{*}{1} & (Constant) & -9.097 & 2.760 & & -3.296 & .002 \\
\hline & Harga & .911 & .205 & .396 & 4.452 & .000 \\
\hline & Kualitas Pelayanan & .789 & .107 & .658 & 7.401 & .000 \\
\hline
\end{tabular}

a. Dependent Variable: Keputusan Pembelian

Sumber: Hasil pengolahan data uji parsial (uji t) menggunakan SPSS versi 22

Berdasarkan hasil pengolahan data pada tabel di atas, diperoleh nilai $t_{\text {hitung }}$ pada variabel $\mathrm{X}_{1}$ (harga) sebesar $4,452>t_{\text {tabel }}$ dengan $\mathrm{df}=\mathrm{n}-\mathrm{k}-1(40-2-1=37)$ sebesar 2,026 atau dengan taraf signifikan $0,000 \leq \alpha$ 0,05 , maka $\mathrm{H}_{0}$ ditolak, artinya harga berpengaruh positif dan signifikan terhadap keputusan pembelian pada PT. Sari Melati Kencana Pematangsiantar Pematangsiantar. Kemudian nilai $t_{\text {hitung }}$ pada variabel $\mathrm{X}_{2}$ (kualitas pelayanan) sebesar 7,401 $>\mathrm{t}_{\text {tabel }}$ dengan $\mathrm{df}=\mathrm{n}-\mathrm{k}-1(40-2-1=37)$ sebesar 2,026 atau dengan taraf signifikan $0,000 \leq \alpha 0,05$, maka $\mathrm{H}_{0}$ ditolak, artinya kualitas pelayanan berpengaruh positif dan signifikan terhadap keputusan pembelian pada PT. Sari Melati Kencana Pematangsiantar.

\section{Uji Simutan (Uji F)}

Pengujian ini dilakukan secara simultan yaitu dilakukan untuk menentukan diterima atau ditolaknya hipotesis, pengujian hipotesis dilakukan untuk menguji apakah variabel harga dan kualitas pelayanan yang diuji berpengaruh terhadap keputusan pembelian. Jika $F_{\text {hitung }}>F_{\text {tabel }}$ atau signifikasi $\leq 0,05$, maka $\mathrm{H}_{0}$ ditolak.

Dengan menggunakan bantuan SPSS versi 22, maka diperoleh hasil perhitungan $F_{\text {hitung }}$ seperti pada tabel berikut ini

Tabel Hasil Uji Simultan (Uji F)

ANOVA $^{a}$

\begin{tabular}{|c|c|c|c|c|c|c|}
\hline & & $\begin{array}{l}\text { Sum of } \\
\text { Squares }\end{array}$ & $d f$ & Mean Square & $\mathrm{F}$ & Sig. \\
\hline \multirow[t]{3}{*}{1} & Regression & 228.183 & 2 & 114.092 & 49.320 & $.000^{b}$ \\
\hline & Residual & 85.592 & 37 & 2.313 & & \\
\hline & Total & 313.775 & 39 & & & \\
\hline
\end{tabular}

b. Predictors: (Constant), Kualitas Pelayanan, Harga

Sumber: Hasil pengolahan data uji simultan (uji F) menggunakan SPSS versi 22

Berdasarkan hasil pengolahan data pada tabel di atas, diperoleh nilai $\mathrm{F}_{\text {hitung }}$ sebesar 49,320 $>\mathrm{F}_{\text {tabel }}$ dengan $\left(0,05 ; 2\right.$ vs 37) sebesar 3,25 atau dengan taraf siginifikan $0,000 \leq \alpha 0,05$ maka $\mathrm{H}_{0}$ ditolak, artinya harga dan kualitas pelayanan berpengaruh positif dan signifikan terhadap keputusan pembelian pada PT. Sari Melati Kencana Pematangsiantar Pematangsiantar.

\section{REFERENSI}

Alma, Buchari.2014.Manajemen Pemasaran dan Pemasaran Jasa. Bandung: Alfabeta Assauri, Sofjan.2013.Manajemen Pemasaran.Jakarta: Rajawali Pers 
Jurnal Ekonomi \& Ekonomi Syariah Vol 3 No 1, Januari 2020

E-ISSN : 2599-3410 | P-ISSN : 2614-3259

DOI : https://doi.org/10.36778/jesya.v3i1.128

Aziz, Anton Mulyono dan Maya Irjayanti.2014.Manajemen.Bandung: Mardika Group

Buchory, Herry Achmad dan Djaslim Saladin.2012.Manajemen pemasaran (Ringkasan praktis, teori, aplikasi \& tanya jawab).Bandung: Lindakarya

Fahmi, Irham.2014. Manajemen: teori, kasus, dan solusi.Bandung: Alfabet

Ghozali, Imam.2016.Aplikasi Analisis Multivariate Dengan Program SPSS.Semarang: Universitas Diponegoro

Griffin, Ricky W.2013.Manajemen Edisi 7 dialih bahasakan oleh Gina Gania Jilid 1.Jakarta: Erlangga

Hasan, Ali.2013.Marketing dan Kasus-Kasus Pilihan.Yogyakarta: CAPS (Center For Academic Publishing Service)

Hasibuan, Malayu S.P.2016.Manajemen Sumber Daya Manusia Edisi Revisi.Jakarta: PT Bumi Aksara

Hurriyati, Ratih.2015.Bauran Pemasaran dan Loyalita Konsumen.Bandung: Alfabeta

Kotler Philip dan Gary Amstrong.2013.Prinsip-prinsip Pemasaran, Edisi ke-12.Jakarta: Erlangga

Kotler, Philip dan Gary Amstrong.2014.Principles of Marketing 12 $2^{\text {th }}$ Edition, Jilid 1 Terjemahan Bob Sabran.Jakarta: Erlangga

Kotler, Philip dan Kevin Lane Keller.2013.Manajemen Pemasaran, Jilid 2, Edisi 13.Erlangga

Kotler, Philip dan Kevin Lane Keller.2016.Marketing Management $15^{\text {th }}$ Edition.Pearson Education,Inc Kotler, Philip and Keller, Kevin Lane. 2012. Marketing Management. 14th edition. New Jersey: Prentice 